\title{
EGY AUTOMATA ÉS EGY EMPIRIKUS LÉGCIRKULÁCIÓS OSZTÁLYOZÁSI RENDSZER ÖSSZEHASONLÍTÓ ELEMZÉSE A KÁRPÁT-MEDENCÉRE
}

\author{
KLICÁSZ SZPIROSZ-PANAGIOTIS MAHERAS-KONSTANTINA TOLIKA \\ -IOANNIS TEGOULIAS \\ -CHRISTINA ANAGNOSTOPOULOU-KÁROSSY CSABA-MAKRA LÁSZLÓ \\ COMPARATIVE ANALYSIS OF EMPIRICAL AND \\ AUTOMATED CLASSIFICATION METHODS FOR CLASSIFYING ATMOSPHERIC \\ CIRCULATION TYPES OVER THE CARPATHIAN BASIN
}

\begin{abstract}
The aim of the study is to compare the performance of the two classification methods based on the atmospheric circulation types over the Pannonian basin in Central Europe. Relationships including seasonal occurrences and correlation coefficients, as well as comparative diagrams of the seasonal occurrences of the circulation types of the two classification systems are presented. When comparing the automated (objective) and empirical (subjective) classification methods, it was found that the frequency of the empirical anticyclonic (or cyclonic) types is much higher (or lower) than that of the automated anticyclonic (cyclonic) types both on an annual and seasonal basis. The highest and statistically significant correlations between the circulation types of the two classification systems, as well as those between the cumulated seasonal anticyclonic and cyclonic types, occur in winter for both classifications, since the weather-influencing effect of the atmospheric circulation in this season is the most prevalent. Precipitation levels in Budapest display a decreasing trend in accordance with the decrease in the occurrence of the automated cyclonic types. In contrast, the occurrence of the empirical cyclonic types displays an increasing trend. There occur types in a given classification that are usually accompanied by high ratios of certain types in the other classification.
\end{abstract}

Keywords: objective circulation types, subjective circulation types, correlation analysis, trends

\section{Bevezetés}

A cirkuláció a légáramlások komplex rendszere, jellegzetes térbeli komponensekkel, valamint ismétlődő időbeli elemekkel. Ahhoz, hogy mélyebb betekintést nyerhessünk a légköri cirkulációba, s hogy jobban megérthessük ezt a folyamatot, a szinoptikus rendszereket általában osztályozzák. A nagyskálájú időjárási helyzetek osztályozásakor három kategóriát különböztetünk meg: (1) manuális (szubjektív) (pl. PÉcZELY GY. 1983), (2) automatizált (objektív) (pl. MAHERAS, P. et al. 2000a) és (3) hibrid osztályozást (pl. SHERIDAN, S.C. 2002). Ugyanakkor meg kell jegyeznünk, hogy az automatizált módszerek, amelyeket általában objektívnek tekintenek, mindig tartalmaznak szubjektív döntéseket is, valamint a hibrid módszerek szubjektív módon definiálják a típusokat, majd számszerúen megragadják a típusok fó jellemzőit, s azok alapján a teljes megfigyelési rendszert automatikusan határozzák meg (PHILIPP, A. et al. 2010).

A cirkuláció időjárási típusok szerinti szubjektív osztályozása hasznos eszköz az éghajlati változások és hatások vizsgálatára (pl. MAKRA, L. 2005; MAKRA, L. et al. 2007a, b; KASSOMENOS, P. A. et al. 2007). Az utóbbi harminc év folyamán számtalan kutatás foglalkozott különböző régiók cirkulációi közötti kapcsolatok összehasonlításával. Ezek közül kiemelendők van LoON, H. - Rogers, J. C. (1978), MAHERAs, P. et al. (1999a, b), Kutiel, H.-Benaroch, Y. (2002), Kutiel, H. et al. (2002), valamint Anagnostopoulou, C. et al. (2004) munkái. Ugyanakkor az egyazon régió cirkulációs típusait vizsgáló, egymás- 
tól különböző osztályozási módszerek közötti kapcsolatokat mindeddig kevéssé kutatták (Jones, P. D. et al. 1993; MAKRA, L. 2006; MAKRA, L. et al. 2009; MAKRA L. 2012).

Jelen dolgozatunkban két osztályozási módszer eredményeit hasonlítjuk össze, egyazon terület cirkulációs típusait alapul véve. Nevezetesen, a MAHERAS, P. et al. (2000a, b) és az ANAGNOSTOPOULOU, C. et al. (2009) által alkalmazott automatikus osztályozást vetjük össze PÉCZELY Gy.(1983) és KáROSsY, Cs. (2004) empirikus osztályozási módszerével, az 19582010 közötti - Magyarország egész területéről gyűjtött - adatok alapján. A napi Péczelytípusok már napjainkig rendelkezésre állnak Magyarország területére (KÁROSSY Cs. 2016).

\section{Adatok és módszerek}

A tanulmányban a NCEP/NCAR adatbázis 1958-2010 közötti 53 éves, 2,5므, $5^{\circ}$ térbeli felbontású napi rácsponti geopotenciál-adatait használtuk az 1000 hPa-os szintre (KALNAY, E. et al. 1996). Ezen adatok alapján egy frissített automatizált, s Európa tetszőleges régióira is alkalmazható osztályozási rendszer (ANAGNOSTOPOULOU, C. et al. 2009) segítségével napi cirkulációs típusokat határoztunk meg. A választott térbeli ablak a $20^{\circ} \mathrm{N}-75^{\circ} \mathrm{N}$ földrajzi szélesség és a $25^{\circ} \mathrm{W}-50^{\circ} \mathrm{E}$ földrajzi hosszúság közötti terület, míg az osztályozás középpontjául Budapestet $\left(j=47,50^{\circ} \mathrm{N}, 1=20,00^{\circ} \mathrm{E}\right)$ választottuk. Ezt az osztályozási rendszert nem közvetlenül a geopotenciál-értékekre alkalmaztuk, hanem azok anomáliáira, az 1971-2000 közötti 30 éves időszak napi adataiból képzett havi közepes geopotenciál-értékekhez viszonyítva.

Budapest - mint középső rácspont $\left(j=47,50^{\circ} \mathrm{N}, 1=20,00^{\circ} \mathrm{E}\right)$ - körül 9 rácspontot vettünk föl a $2,5 \times 2,5^{\circ}$ térbeli felbontású napi rácsponti geopotenciál-mezóben. A napi anticiklonális és a ciklonális típusok meghatározásához a mező napi összes anomália-értékeit mint átlagot összehasonlítottuk e 9 pont napi átlagos anomáliáival, kivéve a Budapestet reprezentáló középső pontot. Egy napot anticiklonális napként jellemeztünk, ha a Budapestet leszámítva megmaradó 8 pontra számított átlagos napi anomália értéke pozitív volt, míg ciklonális napot kaptunk, ha az negatív volt. Ezenkívül a napi teljes anomália-mezőket megvizsgáltuk, hogy minden egyes napra meghatározhassuk a Magyarország időjárását befolyásoló anticiklon, illetve ciklon centrumának földrajzi helyzetét.

Miután meghatároztuk a napi időjárási típusokat Magyarország területére, számos további paramétert is kiszámítottunk évi, illetve évszakos adatok alapján, amelyek a következők: a cirkulációs típusok évszakos gyakorisága, ezek trendjei (mind az anticiklonális, mind pedig a ciklonális típusokra), valamint az egyes típusok átlagos térképei. Végül számos egyéb paramétert is meghatároztunk abból a célból, hogy a cirkulációs típusok és a csapadékmennyiségek közötti kapcsolatot elemezhessük a vizsgált terület fölött (1.ábra).

A Péczely-féle empirikus osztályozás a Kárpát-medence fölött áthaladó ciklonok és anticiklonok aktuális földrajzi pozícióján alapszik, ami figyelembe veszi a hideg- és melegfrontok aktuális pozícióit is. A 13 Péczely-féle típust szerzője öt csoportba sorolta, amelyek a következők: (1) meridionális - északi, (2) meridionális - déli, (3) zonális - nyugati, (4) zonális - keleti és (5) centrális típus (PÉCZELY GY. 1961, 1983). Megjegyezzük, hogy ezt a regionális osztályozást csak a Péczely-típusok sorrendezésénél használjuk fel.

A csapadék-adatbázis az Országos Meteorológiai Szolgálattól származik. Abbéli tapasztalataink alapján, amelyek az elmúlt 40 év során a Görögország területére, továbbá Európa egyéb területeire készített empirikus és objektív cirkulációs tipizálásokat érintik, kijelenthetjük, hogy a csapadék figyelembevétele az anticiklonális és ciklonális típusokhoz az empirikus vagy objektív cirkulációs tipizálás validálásának legfontosabb kritériuma. Ugyanis minél kisebb csapadékhányad kapcsolódik az anticiklonális típusokhoz, annál jobb a tipizálás. Összességben megállapíthatjuk, hogy az 1000 hPa-os abszolút topográfia geopotenciális 


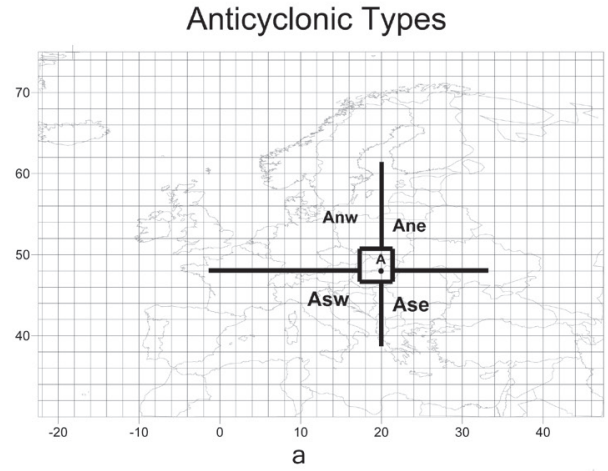

Anticyclonic Types

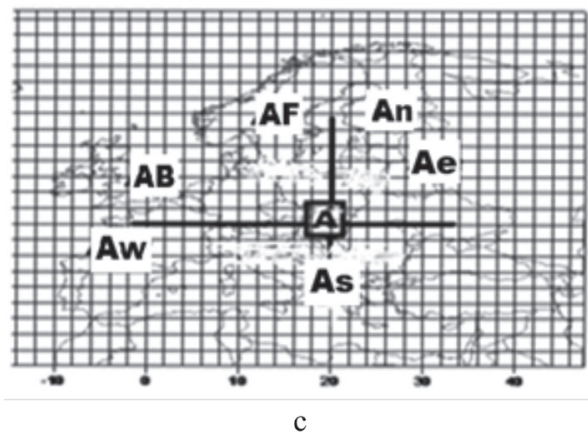

Cyclonic Types

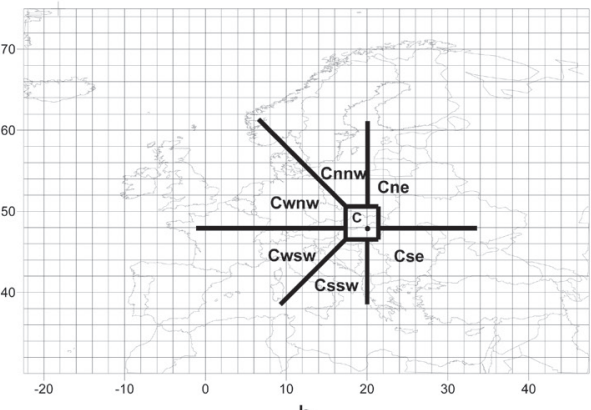

Cyclonic Types

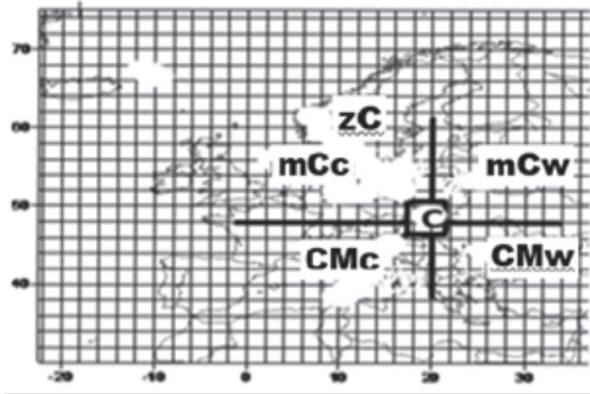

d

1. ábra A Maheras-féle anticiklonális (a), ciklonális (b) és a Péczely-féle anticiklonális (c) ciklonális (d) extrém időjárási típusok központja és földrajzi helyzete

Figure 1 Centres and geographical locations of the Maheras (anticyclonic: a; cyclonic: b) and the Péczely (anticyclonic: c; cyclonic: d) extreme weather types

magasságértékeinek, valamint a tengerszinti légnyomásadatoknak a felhasználása jelentősen hozzájárulhat a kapott rendszer validálásához. Ugyanakkor - tapasztalataink szerint - a hőmérsékletnek vagy más meteorológiai elemnek nincs számottevő hozzáadott értéke a validációhoz.

A két osztályozási rendszer összehasonlítása a következőön alapszik: (1) az évi és évszakos adatokon alapuló cirkulációs típusok bekövetkezési gyakoriságainak vizsgálata, valamint a gyakorisági trendek tanulmányozása; (2) az egyes cirkulációs (anticiklonális és ciklonális) típusokhoz tartozó éves és évszakos csapadékmennyiségek és azok trendjei; (3) a havi tengerszinti légnyomás értékek kiszámítása a Budapest állomáshoz legközelebb esô rácspontra; (4) a rácspontokra vonatkozó korrelációs együtthatók kiszámítása; (5) a két osztályozási rendszer cirkulációs típusai évszakos bekövetkezési gyakoriságainak összehasonlító diagramjai.

\section{Eredmények}

Az anticiklonális és ciklonális típusok évi és évszakos gyakoriságai a két osztályozási rendszerben

Anagnostopoulou, C. et al. (2009) objektív módszere alapján a Magyarország fölötti cirkulációs típusokat az $1000 \mathrm{hPa}$-os geopotenciális magasság figyelembevételével osztályoztuk, majd kiszámoltuk és - a terjedelmi korlátok miatt - csupán a télre (decem- 
ber-februárra) ábrázoltuk a típusok átlagos abszolút topográfiai (geopotenciál-) térképeit (2.ábra). Ehhez hasonlóan elóállítottuk az empirikus, szubjektív Péczely-típusok közepes tengerszinti légnyomási térképeit is az észak-atlanti-európai térségre (3. ábra).
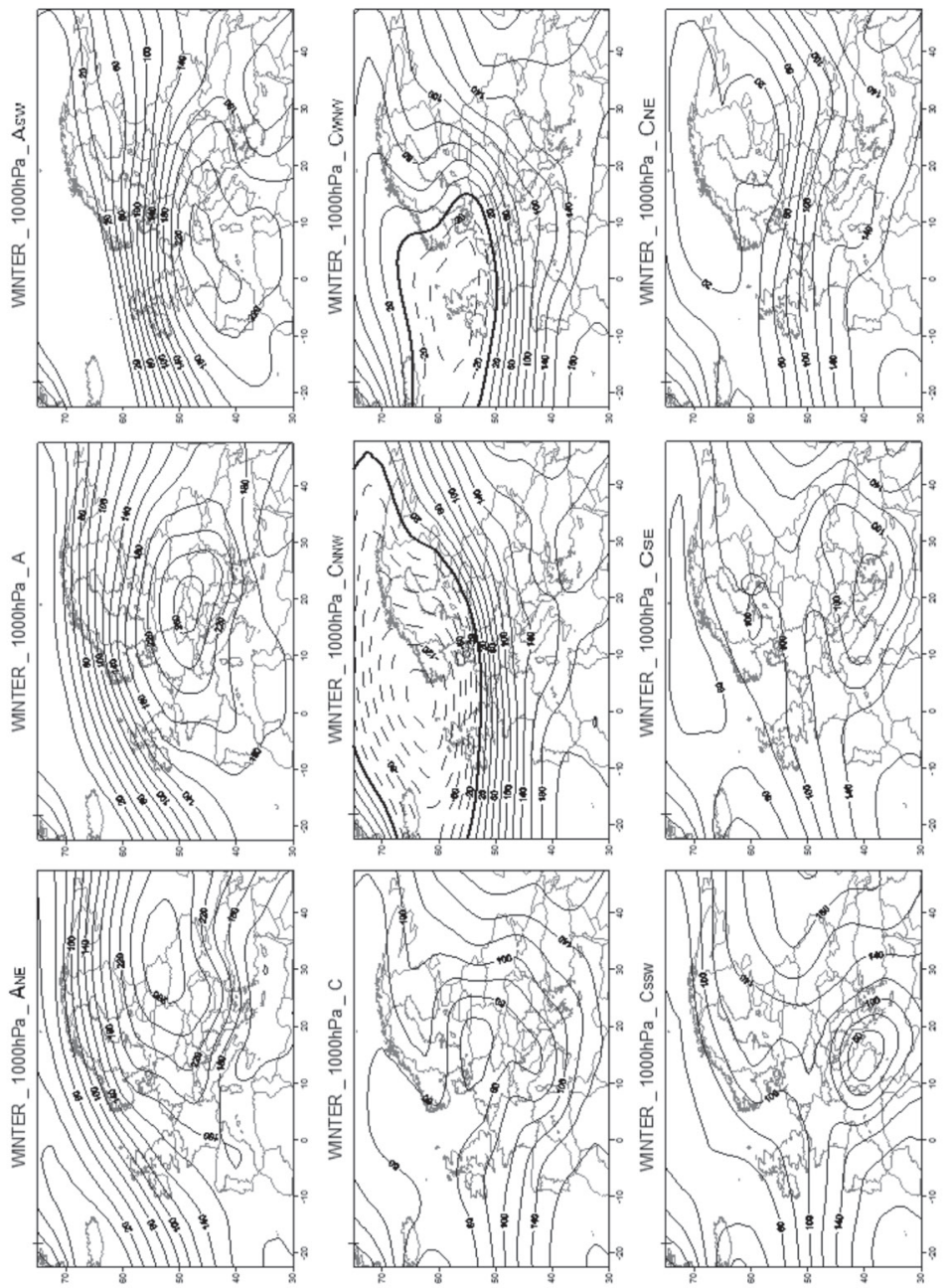

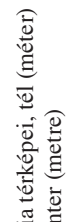
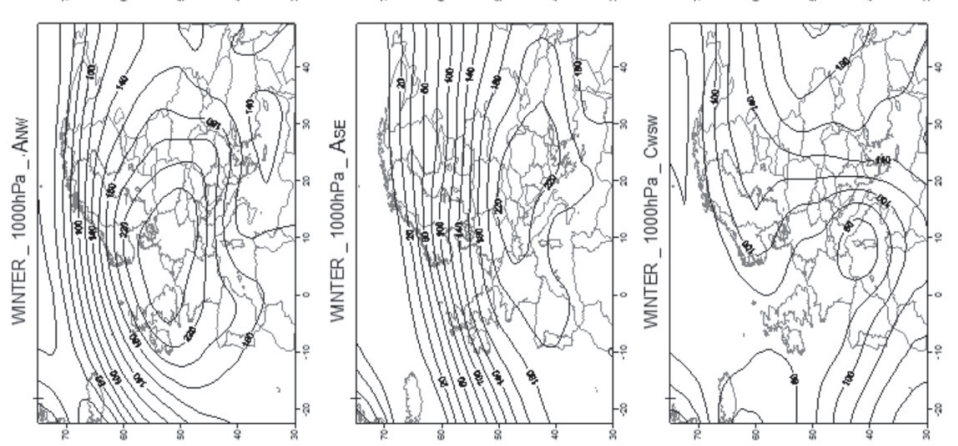

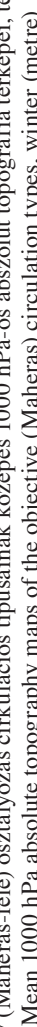

造

每

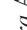

$\frac{5}{2}$ $\dot{i}$ 

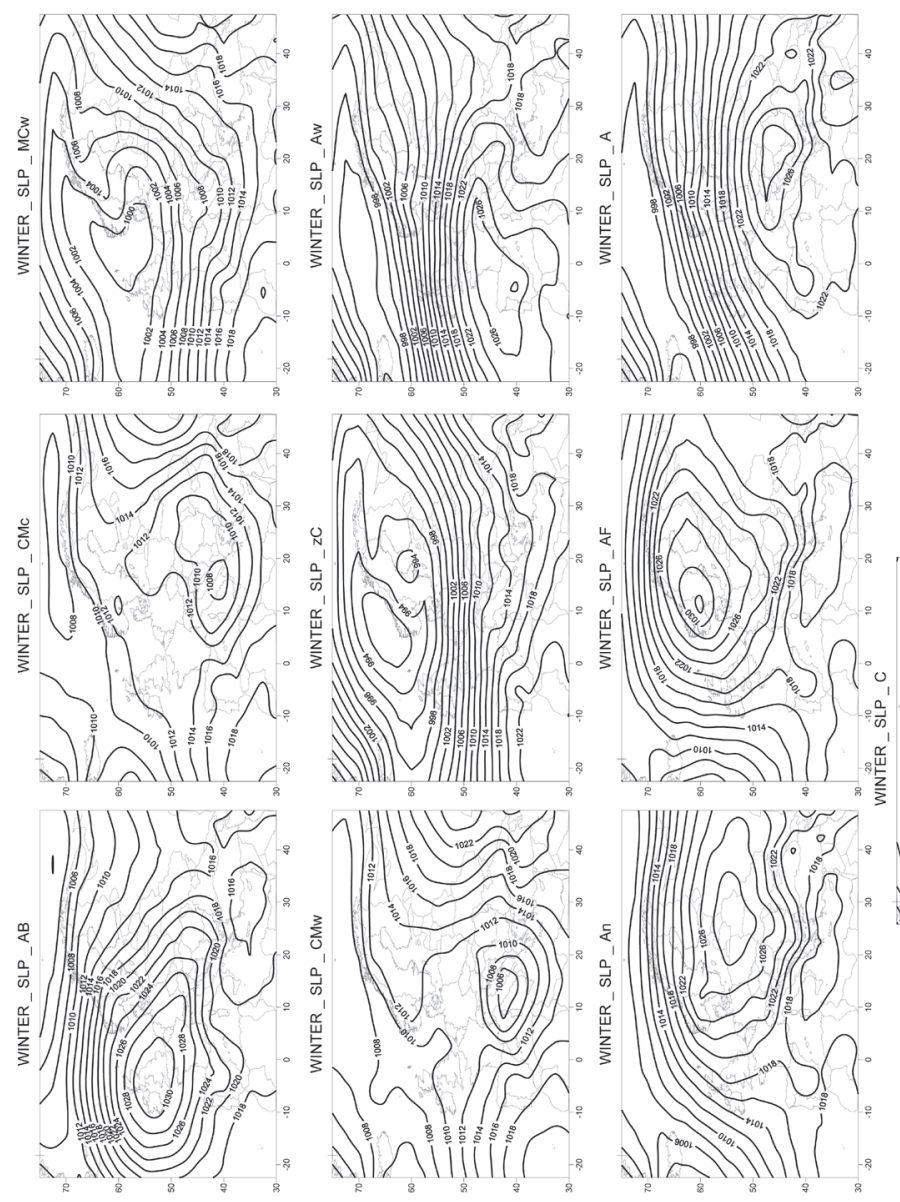

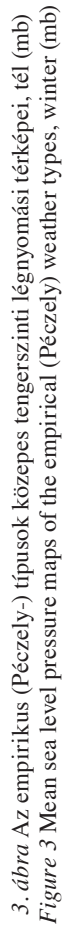
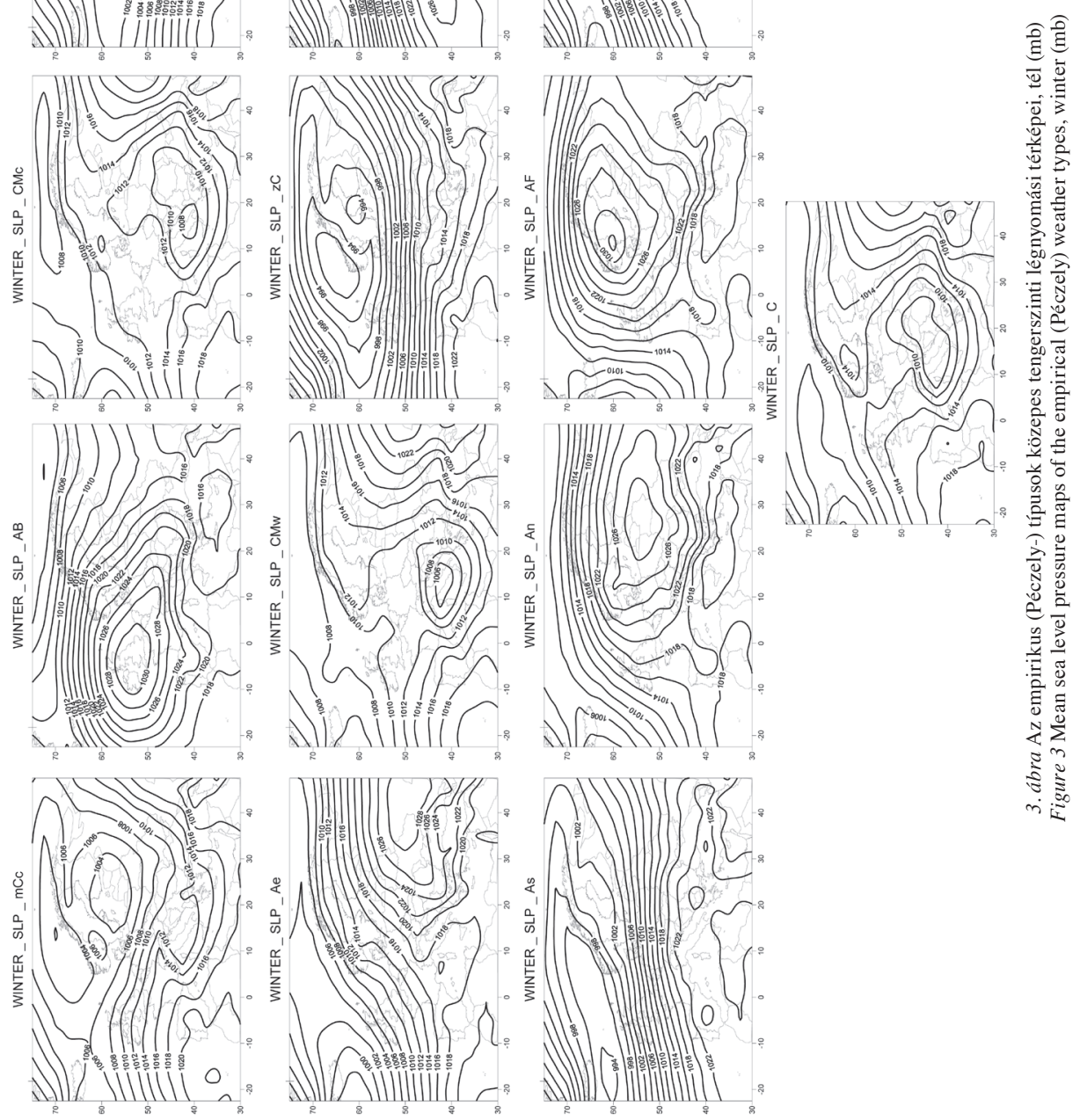

Az objektív Maheras-típusok esetében az anticiklonok (ciklonok) gyakorisága éves szinten 49,6\% (50,4\%) (1. táblázat), míg ugyanezek a Péczely-típusokra 66,1\% (33,9\%) (2. táblázat).

Évszakosan az extrém légnyomási képződmények gyakorisága a két osztályozási rendszerre a következőképp alakul. Az automatizált (Maheras-) klasszifikáció esetében a ciklonális (anticiklonális) típusok gyakorisága télen 60,9\% (39,1\%), tavasszal 58,0\% (42,0\%), 
Az objektív (Maheras-féle) cirkulációs típusok évszakos gyakoriságai

Magyarország fölött (Budapest, 1958-2010)

Seasonal frequencies of the objective (Maheras) circulation types over Hungary (Budapest, 1958-2010)

\begin{tabular}{|c|c|c|c|c|c|c|}
\hline \multirow{2}{*}{ Kód } & \multirow{2}{*}{ Típus } & \multirow{2}{*}{ Leírás } & \multicolumn{4}{|c|}{ Előfordulás, \% } \\
\hline & & & tél & tavasz & nyár & ösz \\
\hline 1 & $\mathrm{~A}_{\mathrm{NW}}$ & $\begin{array}{l}\text { anticiklon centrum } \\
\text { Magyarországtól ÉNy-ra }\end{array}$ & 9,1 & 9,0 & 8,6 & 10,2 \\
\hline 2 & $\mathrm{~A}_{\mathrm{NE}}$ & $\begin{array}{l}\text { anticiklon centrum } \\
\text { Magyarországtól ÉK-re }\end{array}$ & 6,2 & 9,3 & 15,7 & 8,4 \\
\hline 3 & A & $\begin{array}{l}\text { anticiklon centrum } \\
\text { Magyarország fölött }\end{array}$ & 7,4 & 7,9 & 9,6 & 6,5 \\
\hline 4 & $\mathrm{~A}_{\mathrm{SW}}$ & $\begin{array}{l}\text { anticiklon centrum } \\
\text { Magyarországtól DNy-ra }\end{array}$ & 8,3 & 8,2 & 15,4 & 10,3 \\
\hline 5 & $\mathrm{~A}_{\mathrm{SE}}$ & $\begin{array}{l}\text { anticiklon centrum } \\
\text { Magyarországtól DK-re }\end{array}$ & 8,1 & 7,6 & 15,4 & 16,7 \\
\hline 6 & $\mathrm{C}$ & $\begin{array}{l}\text { ciklon centrum } \\
\text { Magyarország fölött }\end{array}$ & 5,9 & 8,6 & 5,6 & 6,2 \\
\hline 7 & $\mathrm{C}_{\mathrm{NNW}}$ & $\begin{array}{l}\text { ciklon centrum } \\
\text { Magyarországtól ÉÉNy-ra }\end{array}$ & 5,0 & 3,6 & 1,9 & 3,9 \\
\hline 8 & $\mathrm{C}_{\mathrm{WNW}}$ & $\begin{array}{l}\text { ciklon centrum } \\
\text { Magyarországtól ÉNyNy-ra }\end{array}$ & 7,0 & 6,2 & 4,0 & 4,7 \\
\hline 9 & $\mathrm{C}_{\mathrm{WSW}}$ & $\begin{array}{l}\text { ciklon centrum } \\
\text { Magyarországtól NyDNy-ra }\end{array}$ & 10,3 & 8,0 & 6,6 & 8,9 \\
\hline 10 & $\mathrm{C}_{\mathrm{SSW}}$ & $\begin{array}{l}\text { ciklon centrum } \\
\text { Magyarországtól DDNy-ra }\end{array}$ & 3,2 & 4,6 & 3,1 & 4,1 \\
\hline 11 & $\mathrm{C}_{\mathrm{SE}}$ & $\begin{array}{l}\text { ciklon centrum } \\
\text { Magyarországtól DK-re }\end{array}$ & 13,4 & 11,9 & 6,0 & 11,0 \\
\hline 12 & $\mathrm{C}_{\mathrm{NE}}$ & $\begin{array}{l}\text { ciklon centrum } \\
\text { Magyarországtól ÉK-re }\end{array}$ & 16,1 & 15,1 & 8,3 & 9,1 \\
\hline
\end{tabular}

nyáron 35,3\% (64,7\%) és ősszel 47,9\% (52,1\%) (1. táblázat). Ugyanakkor az empirikus (Péczely-féle) osztályozás alkalmazásával a ciklonális (anticiklonális) típusok a következő arányban fordulnak elő: tél: 34,5\% (65,5\%), tavasz: 40,7\% (59,3\%), nyár: 29,9\% (70,1\%), és ősz: 30,5\% (69,5\%) (2. táblázat).

Összességében megállapíthatjuk, hogy a legnagyobb eltérés a két osztályozási rendszer között télen (26,4\%), míg a legkisebb nyáron tapasztalható $(5,4 \%)$ (1., 2. táblázat).

Amikor végrehajtjuk az objektív tipizálást, az anticiklonális típusok közül évi átlagban az $\mathrm{A}_{\mathrm{SE}}$ a leggyakoribb (11,9\%), amelyet az $\mathrm{A}_{\mathrm{SW}}$ követ (10,6\%). A ciklonális típusok közül a $\mathrm{C}_{\mathrm{NE}}(12,3 \%)$ és a $\mathrm{C}_{\mathrm{SE}}(10,7 \%)$ lép föl a leggyakrabban (1. táblázat; 1. ábra). Ami az empirikus (Péczely-) osztályozást illeti, évi átlagban az anticiklonális típusok közül az Aw típus a leggyakoribb (14,6\%), amelyet az Ae típus követ (12,6\%). Ugyanakkor a ciklonális típusok közül az mCc $(9,7 \%)$ és az $\mathrm{mCw}(7,9 \%)$ lép föl a leggyakrabban (2.táblázat).

Télen az objektív osztályozást tekintve az anticiklonális $\mathrm{A}_{\mathrm{NW}}$ típus a leggyakoribb $(9,1 \%)$, amit rendre az $\mathrm{A}_{\mathrm{SW}}(8,3 \%)$ és az $\mathrm{A}_{\mathrm{SE}}(8,1 \%)$ típus követ. A ciklonális típusok közül a $\mathrm{C}_{\mathrm{NE}}$ fordul eló a leggyakrabban $(16,1 \%)$, csaknem kétszer olyan gyakorisággal, mint az $\mathrm{A}_{\mathrm{NW}}$ típus. Ugyanakkor a $\mathrm{C}_{\mathrm{SE}}$ típus sorrendben a második $(13,4 \%)$ (1. táblázat; 1. ábra). 
Az empirikus (Péczely-féle) cirkulációs típusok évszakos gyakoriságai

Magyarország fölött (Budapest, 1958-2010)

Seasonal frequencies of the empirical (Péczely) circulation types over Hungary (Budapest, 1958-2010)

\begin{tabular}{|c|c|c|c|c|c|c|c|}
\hline \multirow{2}{*}{ Kód } & \multirow{2}{*}{ Típus } & \multirow{2}{*}{ Leírás } & \multicolumn{4}{|c|}{ Előfordulás, \% } & \multirow{2}{*}{$\begin{array}{l}\text { Évi gya- } \\
\text { koriság }\end{array}$} \\
\hline & & & tél & tavasz & nyár & Øsz & \\
\hline 1 & $\mathrm{mCc}$ & $\begin{array}{l}\text { ciklon hidegfrontjával É-Európa } \\
\text { fölött, északi szél }\end{array}$ & 7,3 & 11,3 & 12,1 & 8,0 & 9,7 \\
\hline 2 & $\mathrm{AB}$ & $\begin{array}{l}\text { anticiklon a Brit-szigetek fölött, } \\
\text { északi szél }\end{array}$ & 5,6 & 7,1 & 8,6 & 6,4 & 6,9 \\
\hline 3 & $\mathrm{CMc}$ & $\begin{array}{l}\text { mediterrán ciklon } \\
\text { hidegfrontjával D-Európa fölött, } \\
\text { északi szél }\end{array}$ & 2,5 & 3,5 & 1,8 & 1,9 & 2,4 \\
\hline 4 & $\mathrm{mCw}$ & $\begin{array}{l}\text { mediterrán ciklon meleg- } \\
\text { frontjával ÉK-Európa fölött, déli } \\
\text { szél }\end{array}$ & 9,2 & 9,7 & 5,7 & 7,2 & 7,9 \\
\hline 5 & $\mathrm{Ae}$ & $\begin{array}{l}\text { anticiklon K-Európa fölött, } \\
\text { déli szél }\end{array}$ & 14,2 & 11,3 & 7,3 & 17,6 & 12,6 \\
\hline 6 & $\mathrm{CMw}$ & $\begin{array}{l}\text { mediterrán ciklon meleg- } \\
\text { frontjával D-Európa fölött, déli } \\
\text { szél }\end{array}$ & 8,9 & 8,7 & 3,7 & 8,3 & 7,4 \\
\hline 7 & $\mathrm{zC}$ & $\begin{array}{l}\text { erôsen fejlett ciklon É-Európa } \\
\text { fölött, nyugati szél }\end{array}$ & 5,0 & 3,2 & 2,7 & 2,9 & 3,5 \\
\hline 8 & Aw & $\begin{array}{l}\text { anticiklon Ny-Európa fölött, } \\
\text { nyugati szél }\end{array}$ & 13,1 & 11,2 & 20,8 & 12,8 & 14,6 \\
\hline 9 & As & $\begin{array}{l}\text { anticiklon D-Európa fölött, } \\
\text { nyugati szél }\end{array}$ & 7,0 & 4,4 & 2,9 & 5,6 & 4,9 \\
\hline 10 & An & $\begin{array}{l}\text { anticiklon É-Európa fölött, } \\
\text { keleti szél }\end{array}$ & 10,9 & 12,8 & 11,3 & 10,1 & 11,3 \\
\hline 11 & $\mathrm{AF}$ & $\begin{array}{l}\text { anticiklon Fennoskandinávia } \\
\text { fölött, keleti szél }\end{array}$ & 2,8 & 5,2 & 5,9 & 3,7 & 4,4 \\
\hline 12 & A & $\begin{array}{l}\text { anticiklon a Kárpát-medence } \\
\text { fölött, változó szélirány }\end{array}$ & 11,8 & 7,3 & 13,3 & 13,3 & 11,4 \\
\hline 13 & $\mathrm{C}$ & $\begin{array}{l}\text { ciklon a Kárpát-medence fölött, } \\
\text { változó szélirány }\end{array}$ & 1,7 & 4,3 & 3,9 & 2,2 & 3,0 \\
\hline
\end{tabular}

Ami az empirikus osztályozást illeti, az anticiklonális típusok közül az Ae (14,2\%) és az Aw $(13,1 \%)$ a leggyakoribb, míg a ciklonális típusok közül az mCw $(9,2 \%)$ és a CMw $(8,9 \%)$ fordul elő a legtöbb alkalommal (2. táblázat; 3. ábra). Tavasszal az automatizált osztályozás esetében változnak az előfordulási arányok a télihez képest. Az anticiklonális típusok közül az $\mathrm{A}_{\mathrm{NE}}$ a leggyakoribb (9,3\%), amelyet az $\mathrm{A}_{\mathrm{NW}}$ típus követ (9,0\%), míg a ciklonális típusok közül a $\mathrm{C}_{\mathrm{NE}}(15,1 \%)$ és a $\mathrm{C}_{\mathrm{SE}}(11,9 \%)$ a leggyakoribb (1.táblázat; 1 ., 2. ábra). Az empirikus osztályozás szerint az anticiklonális An $(12,8 \%)$ és Ae $(11,3 \%)$ típusok fordulnak elő a legtöbbször (2. táblázat; 3. ábra). Nyáron az objektív tipizálás alapján az anticiklonális típusok közül az $\mathrm{A}_{\mathrm{NE}}(15,7 \%)$, az $\mathrm{A}_{\mathrm{SW}}(15,4 \%)$ és az $\mathrm{A}_{\mathrm{SE}}(15,4 \%)$ (la.ábra; 2.ábra), míg a ciklonális típusok közül a $\mathrm{C}_{\mathrm{NE}}(8.3 \%)$ és a $\mathrm{C}_{\mathrm{WSW}}(6.6 \%)$ a leggyakoribb (1.táblázat; 1b. ábra; 2.ábra). Az empirikus klasszifikáció esetében az anticiklo- 
nális típusok közül az Aw (20,8\%) és az A (13,3\%) fordul elő a legtöbbször. Ugyanakkor a leggyakoribb ciklonális típusok az mCc $(12,1 \%)$ és az $\mathrm{mCw}(5,7 \%)$ (2. táblázat; 3. ábra). Ôsszel az automatizált osztályozás alapján az anticiklonális típusok közül az $\mathrm{A}_{\mathrm{SE}}(16,7 \%)$ és az $\mathrm{A}_{\mathrm{SW}}(10,3 \%)$ a leggyakoribb (1a. ábra; 2. ábra), míg a ciklonális típusok közül a $\mathrm{C}_{\mathrm{SE}}(11,0 \%)$ és a $\mathrm{C}_{\mathrm{NE}}(9,1 \%)$ lép fel a leggyakrabban (1. táblázat; 1b. ábra; 2. ábra). Az empirikus osztályozás esetében az anticiklonális típusok közül a legjellemzôbb az Ae $(17,6 \%)$ és az A $(13,3 \%)$ típus, míg a ciklonálisok közül a CMw $(8,3 \%)$ és az mCc $(8,0 \%)$ helyzet (2. táblázat; 3. ábra).

Az objektív és az empirikus cirkulációs típusok szignifikáns eltérést mutatnak mind évi, mind pedig évszakos összevetésben (3. táblázat). Az összehasonlítást a Mann-Kendallpróba (LANDAU, S.-EvERITT, B. S. 2006) segítségével értékeltük, a 95\%-os valószínúségi szinten. Az objektív osztályozás esetén az ősz kivételével az anticiklonális (ciklonális) típusok gyakorisága statisztikailag szignifikáns növekvő (csökkenő) trendet mutat (az 5\%-os szignifikancia-szinten). Ősszel - bár az előjelük ugyanaz - a trendértékek nem szignifikánsak. Az évszakok közül statisztikailag szignifikáns trendek csupán ősszel tapasztalhatók: az anticiklonális típusok csökkenő trendet mutatnak, míg a ciklonálisak növekvő gyakoriságot jeleznek. Télen a trendek elhanyagolhatók és ez a helyzet tavasszal is. Nyáron az anticiklonális típusok gyakorisága pozitív, míg a ciklonális típusoké negatív trendet mutat, ugyanakkor egyik sem szignifikáns (3. táblázat).

3. táblázat - Table 3

A két osztályozási rendszer ciklonális és anticiklonális típusainak trendjei, 1958-2010

(A szürke cellák szignifikáns trendeket jeleznek az 5\%-os valószínúségi szinten)

Trends of the cyclonic and anticyclonic types of the two classifications systems, 19582010 (Grey cells indicate significant trends at the 5\% probability level)

\begin{tabular}{lcccc}
\hline \multirow{2}{*}{ Időszak } & \multicolumn{2}{c}{ Automatizált (Maheras) típusok } & \multicolumn{2}{c}{ Szubjektív (Péczely) típusok } \\
& anticiklonális & ciklonális & anticiklonális & ciklonális \\
\hline Tél & + & - & - & + \\
Tavasz & + & - & + & - \\
Nyár & + & - & + & - \\
Ôsz & + & - & - & + \\
Év & + & - & - & + \\
\hline
\end{tabular}

A vizsgált időszakra kiszámítottuk az egymásnak megfelelő objektív és az empirikus cirkulációs típusok évi és évszakos előfordulási gyakoriságai közötti korrelációs együtthatókat, részben a kumulált ciklonális/anticiklonális típusokra, részben pedig az egyes típusokra.

A 4 táblázat csupán azokat a páronkénti cirkulációs típusokat mutatja a két osztályozási rendszert összevetve, amelyekre a korrelációs együtthatók szignifikánsak az 5\%-os valószínúségi szinten. A két osztályozási rendszer anticiklonális vagy ciklonális időjárási típusai közötti pozitív korrelációs együttható úgy interpretálható, mint a két rendszer típusai gyakorisági idősorainak lineáris korrelációi. Ez azt jelenti, hogy például az egyik rendszer anticiklonális típusai gyakoriságainak növekedése összhangban van a másik rendszer anticiklonális típusai gyakoriságainak relatív növekedésével. Ellentétes eset lép fel, amikor a korrelációs együtthatók negatívak, azaz amikor pl. az egyik rendszer anticiklonális típusai gyakoriságainak növekedése összhangban van a másik rendszer ciklonális 
4. táblázat-Table 4

Az objektív és az empirikus típusok közötti statisztikailag szignifikáns korrelációk ( $|r|>0.40$, az 5\%-os valószínúségi szinten)

Statistically significant correlation coefficients between the objective and the empirical types $(|\mathrm{r}|>0.40$, at the 5\% probability level)

\begin{tabular}{|c|c|c|c|}
\hline Év/évszak & Maheras & Péczely & Korrelációs együtthatók \\
\hline \multirow[t]{2}{*}{ Év } & anticiklonális & anticiklonális & 0,49 \\
\hline & ciklonális & ciklonális & 0,49 \\
\hline \multirow[t]{11}{*}{ Tél } & anticiklonális & anticiklonális & 0,74 \\
\hline & ciklonális & ciklonális & 0,74 \\
\hline & $\mathrm{A}_{\mathrm{NW}}$ & $\mathrm{AB}$ & 0,53 \\
\hline & $\mathrm{A}_{\mathrm{NE}}$ & $\mathrm{Ae}$ & 0,63 \\
\hline & A & A & 0,69 \\
\hline & $\mathrm{A}_{\mathrm{SW}}$ & Aw & 0,54 \\
\hline & $\mathrm{A}_{\mathrm{SE}}$ & $\mathrm{A}$ & 0,55 \\
\hline & $\mathrm{C}$ & $\mathrm{CMw}$ & 0,55 \\
\hline & $\mathrm{C}_{\mathrm{WNW}}$ & $\mathrm{mCw}$ & 0,62 \\
\hline & $\mathrm{C}_{\mathrm{WSW}}$ & $\mathrm{CMw}$ & 0,54 \\
\hline & $\mathrm{C}_{\mathrm{SE}}$ & An & 0,56 \\
\hline \multirow[t]{9}{*}{ Tavasz } & anticiklonális & anticiklonális & 0,62 \\
\hline & ciklonális & ciklonális & 0,62 \\
\hline & $\mathrm{A}_{\mathrm{NE}}$ & $\mathrm{Ae}$ & 0,46 \\
\hline & A & $\mathrm{A}$ & 0,42 \\
\hline & $\mathrm{A}_{\mathrm{SW}}$ & An & $-0,58$ \\
\hline & $\mathrm{C}_{\mathrm{WNW}}$ & $\mathrm{mCw}$ & 0,48 \\
\hline & $\mathrm{V}_{\mathrm{WSW}}$ & $\mathrm{CMw}$ & 0,53 \\
\hline & $\mathrm{C}_{\mathrm{SSW}}$ & $\mathrm{CMw}$ & 0,48 \\
\hline & $\mathrm{C}_{\mathrm{SE}}$ & $\mathrm{CMw}$ & 0,43 \\
\hline \multirow[t]{6}{*}{ Nyár } & anticiklonális & anticiklonális & 0,46 \\
\hline & ciklonális & ciklonális & 0,46 \\
\hline & $\mathrm{A}_{\mathrm{NW}}$ & $\mathrm{AB}$ & 0,44 \\
\hline & C & $\mathrm{mCw}$ & 0,44 \\
\hline & $\mathrm{C}_{\mathrm{WNW}}$ & $\mathrm{mCw}$ & 0,44 \\
\hline & $\mathrm{C}_{\mathrm{NE}}$ & $\mathrm{zC}$ & 0,64 \\
\hline \multirow[t]{8}{*}{ Ôsz } & anticiklonális & anticiklonális & 0,69 \\
\hline & ciklonális & ciklonális & 0,69 \\
\hline & A & A & 0,41 \\
\hline & $\mathrm{A}_{\mathrm{SE}}$ & $\mathrm{mCw}$ & $-0,47$ \\
\hline & $\mathrm{C}$ & $\mathrm{mCw}$ & 0,42 \\
\hline & $\mathrm{C}_{\mathrm{WNW}}$ & $\mathrm{mCw}$ & 0,41 \\
\hline & $\mathrm{C}_{\mathrm{WSW}}$ & $\mathrm{mCw}$ & 0,41 \\
\hline & $\mathrm{C}_{\mathrm{SE}}$ & $\mathrm{mCw}$ & 0,53 \\
\hline
\end{tabular}


típusai gyakoriságainak csökkenésével. Megjegyzendő, hogy lehet úgy is szignifikáns a korreláció, hogy nem a trendek párhuzamosak vagy ellentétesek, hanem csak a körülöttük való ingadozás.

A korrelációs együtthatókra két meglehetôsen bonyolult példát mutatunk be az alábbiakban. Ahhoz, hogy értelmezhessük a $\mathrm{C}_{\mathrm{SE}}$ objektív ciklonális típus, valamint az $\mathrm{An}$ empirikus anticiklonális típus közötti pozitív korrelációs együtthatót a téli évszakban, előállítottuk azon napok közepes kompozit térképeit, amelyeken egyidejúleg előfordul a két típus. Megállapítottuk, hogy az An anticiklonális típusnak (empirikus osztályozás) K-en van a központja, s Ny felé terjeszkedik, míg annak a D-i részén ciklogenezist képez egy a Balkán fölötti centrummal, amely lefedi a mediterrán régiót és Magyarországot. Az empirikus osztályozásban ez a cirkulációs típus az anticiklonális An időjárási helyzet, míg az automatizált osztályozásban ez a $\mathrm{C}_{\mathrm{SE}}$ típus. A geopotenciál-anomáliák Magyarország fölött negatívak, következésképp az An gyakoriságának változása maga után vonja a $\mathrm{C}_{\mathrm{SE}}$ gyakoriságának a megváltozását. Az $\mathrm{A}_{\mathrm{SW}}$ objektív és az An empirikus időjárási típusok közötti, tavasszal tapasztalható $\mathrm{r}=-0,58$ korreláció interpretálására elóállítottuk az ekvivalens közepes kompozit térképeket. Megállapítottuk, hogy ez esetben az anticiklon központja Magyarország ÉNy-i része fölött volt, a Brit-szigetek és Skandinávia között, s az kiterjedt délre egy másodlagos anticiklon centrumot képezve Magyarország DNy-i része fölött. Az objektív osztályozásban ez az a centrum, amelyet a szoftvercsomag definiált, mivel az sokkal közelebb van a vizsgált térséghez. A negatív korreláció azzal a ténnyel magyarázható, hogy az $\mathrm{A}_{\mathrm{SW}}$ előfordulási gyakoriságainak a növekedése az An gyakoriságának a csökkenését eredményezi és viszont. A legnagyobb korrelációk télen tapasztalhatók, amikor - összehasonlítva a többi évszakkal - a cirkuláció időjárást befolyásoló hatása a legjellemzőbb (MAKRA L. et al. 2012). A két osztályozási rendszer ciklonális és anticiklonális típusai közötti legmagasabb korrelációs együtthatók is a téli évszakban lépnek föl $(\mathrm{r}=0,74)$. Ezt követik az A típusok közötti téli korrelációk $\left(\mathrm{r}_{\max }=0,69\right)$. Mindössze ezek az A típusok eredményeznek magas korrelációkat a többi évszakban (tavasz: $\mathrm{r}=0,42$, oss: $\mathrm{r}=0,41$ ), a nyár kivételével. Magas korrelációt tapasztaltunk még az $\mathrm{A}_{\mathrm{NE}}$ és az Ae helyzetek gyakoriságai között $(\mathrm{r}=0,63)$, valamint a $\mathrm{C}_{\mathrm{WNW}}$ és az $\mathrm{mCW}$ között $(\mathrm{r}=0,62)$ télen, továbbá a $\mathrm{C}_{\mathrm{NE}}$ és a zC között $(\mathrm{r}=0,64)$ nyáron.

Ahhoz, hogy jobban megérthessük a két osztályozási rendszer közötti összefüggéseket, mindkét cirkulációs rendszerre kiszámítottuk a hozzájuk tartozó cirkulációs típus évszakos előfordulásait. Pontosabban azt, hogy mennyi adott empirikus típus fordul elő egy adott objektív típus fennállásakor. Az eredményeket évszakos diagramok mutatják (4.ábra). Megállapítottuk, hogy egyezést tudunk kimutatni egyrészt egy ritkán vagy gyakran előforduló anticiklonális vagy ciklonális empirikus típus, másrészt egy automatizált típus között. Mivel a cirkulációs típusok évszakos előfordulásai páronkénti egyezésének a vizsgálata igen sok diagramot eredményezett volna, ezért évszakonként rendre egy átlag körüli, illetve egy magas gyakoriságú automatizált típus fennállásakor előforduló összes empirikus típus gyakoriságait mutatjuk be. Télen az objektív osztályozási rendszer A anticiklonális típusa (1.táblázat) mutatja a legszorosabb kapcsolatot az empirikus típusokkal. Az objektív A típus fennállásakor az empirikus A típus fordul elő a leggyakrabban (45\%), míg az empirikus An típus (25\%) a második leggyakoribb. Ugyanebben az évszakban az objektív $\mathrm{C}_{\mathrm{SE}}$ típus fennállásakor az empirikus típusok egy széles spektruma viszonylag magas gyakorisággal figyelhető meg.

Tavasszal az empirikus típusok a legnagyobb koncentrációban az objektív A $_{S W}$ típus fennállásakor fordulnak elő, míg az empirikus Aw típus túlsúlya 41\%-os gyakorisággal érvényesül. Ezenkívül az empirikus típusok második legnagyobb gyakorisága akkor következik be, amikor - az objektív $\mathrm{C}_{\mathrm{NE}}$ típus fennállásakor - az empirikus mCc típus 

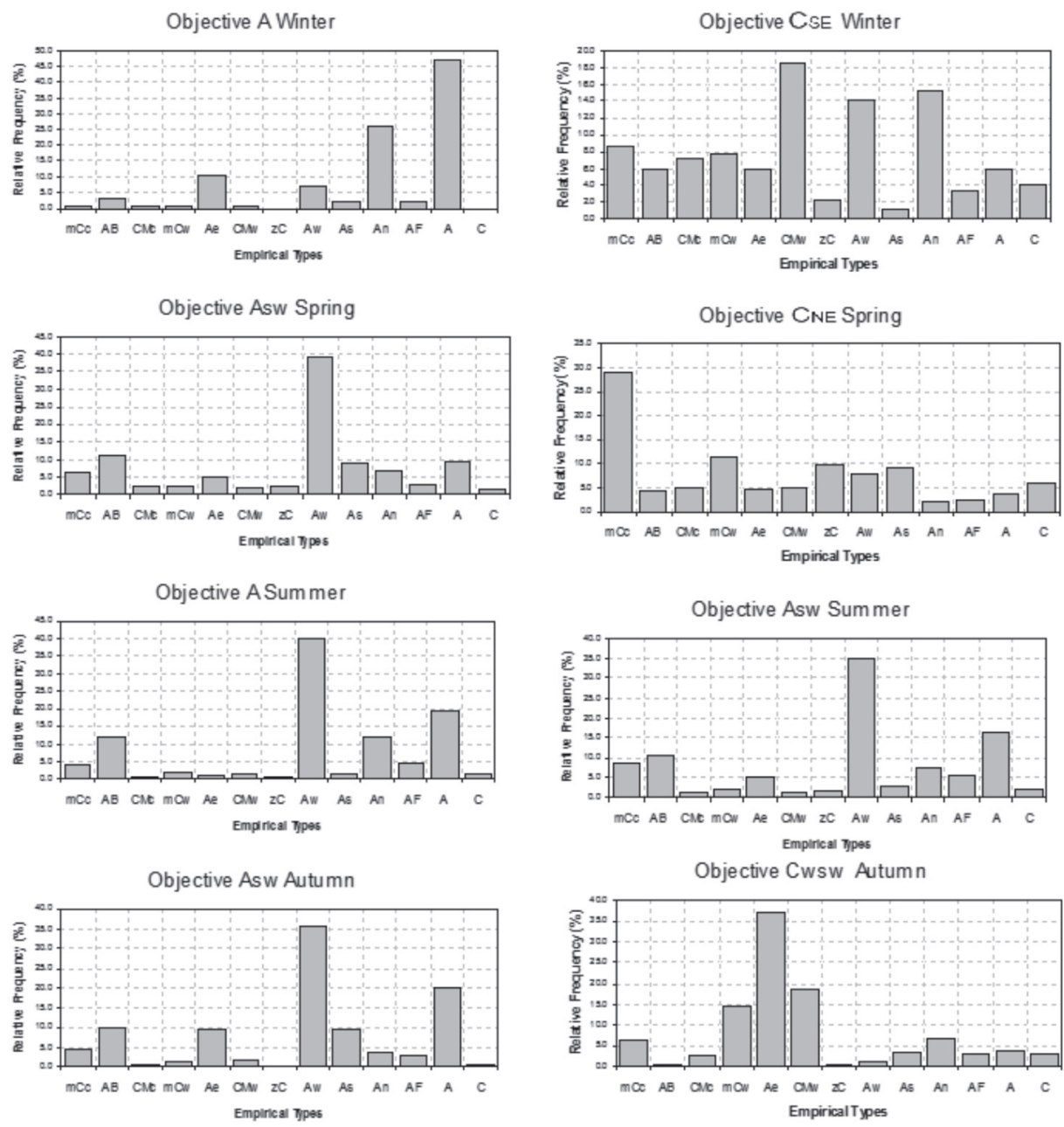

4. ábra Egy átlag körüli, illetve egy magas gyakoriságú automatizált (Maheras-) típus (1. táblázat) fennállásakor előforduló összes empirikus (Péczely-) típus (2. táblázat) relatív gyakorisága a négy évszakra Figure 4 Relative frequency of all empirical (Péczely) types (Table 2) in the case of an average and a high frequency automated (Maheras) type (Table 1) in the four seasons

(29\%) extrém magas gyakorisága tapasztalható (4.ábra). Egy kiválasztott Maheras-típus előfordulásakor a Péczely-típusok előfordulásának relatív gyakorisága jól tükrözi azt, hogy évszakosan mely Péczely-típusok a leginkább hasonlóak a kiválasztott Maheras-típusokhoz.

Két nyári példát mutatunk be az empirikus típusok legmagasabb koncentrációjára egy adott objektív típus bekövetkezésekor. Az A és $A_{S w}$ objektív típusok fennállásakor az empirikus típusok gyakorisági eloszlása majdnem ugyanaz. Mindkét esetben az empirikus Aw típus előfordulása a leggyakoribb, rendre 40\%-ot, illetve 35\%-ot elérve az A, illetve A $\mathrm{SW}$ objektív típusok fennállásakor (4. ábra).

Ósszel az empirikus típusok legmagasabb koncentrációja az objektív $\mathrm{A}_{\mathrm{SW}}$ típus fennállásakor figyelhetô meg. Ugyanakkor az objektív $\mathrm{C}_{\mathrm{WSW}}$ típus szoros kapcsolatot mutat az empirikus Ae típussal (37\%) (4. ábra). 


\section{Cirkulációs típusok és a csapadék Budapesten}

Ahhoz, hogy tovább elemezzük a cirkulációs típusok arányait, meghatároztuk a Budapesten mért csapadékmennyiségeket mindkét osztályozási rendszer mindegyik időjárási típusára, mind évi, mind pedig évszakos összesítésben ( $5 a$., 5 b. táblázat).

Ami az objektív osztályozást illeti, a ciklonális típusok a felelősek az évi össz-csapadék 77,4\%-áért, míg az anticiklonális típusok a maradék 22,6\%-áért. Az összes ciklonális típus közül a legcsapadékosabb a $\mathrm{C}_{\mathrm{WSW}}(16,7 \%)$ és a $\mathrm{C}(16,5 \%)$. Továbbá a mért csapadékmennyiség jelentôs része kapcsolódik a $\mathrm{C}_{\mathrm{SE}}$ típushoz $(11,4 \%)$, míg a délies szelekért felelős típusok ritkábban fordulnak eló és szintén jelentős mennyiségú csapadékkal járnak $\left(\mathrm{C}_{\mathrm{WNW}}, 9,9 \%\right.$ és $\left.\mathrm{C}_{\mathrm{SSW}}, 8,7 \%\right)$.

Télen a legnagyobb csapadékok a ciklonális típusok elófordulásakor hullanak $(94,2 \%)$, míg az anticiklonális típusok járnak a legkevesebb csapadékkal (5,8\%). A ciklonális típusok közül a $\mathrm{C}_{\mathrm{WSW}}(23,4 \%)$ és a $\mathrm{C}_{\mathrm{WNW}}(18,2 \%)$ a leginkább csapadékérzékeny, ezeket rendre a $\mathrm{C}(15,7 \%), \mathrm{C}_{\mathrm{NE}}(13,4 \%)$, a $\mathrm{C}_{\mathrm{SE}}(9,6 \%)$ és a $\mathrm{C}_{\mathrm{NNW}}(8,2 \%)$ típusok követik csökkenő sorrendben (5a.táblázat). A ciklonális típusokhoz köthetô tavaszi csapadékmennyiség aránya sorrendben a harmadik $(82,2 \%)$. Következésképp a második legkisebb csapadékmennyiség az anticiklonális típusoknál figyelhetô meg (17,8\%). Tavasszal a legcsapadékosabb ciklonális típus a $\mathrm{C}(22,0 \%)$, amelyet a $\mathrm{C}_{\mathrm{WSW}}(14,8 \%)$, a $\mathrm{C}_{\mathrm{SE}}(13,6 \%)$ és a $\mathrm{C}_{\mathrm{NE}}(13,2 \%)$ követ csökkenő sorrendben. A ciklonális típusoknál a legalacsonyabb csapadékmennyiség nyáron fordul elő $(57,3 \%)$, ugyanakkor az anticiklonális típusoknál ekkor hullik a legtöbb csapadék (42,7\%). A legcsapadékosabb ciklonális típusok nyáron rendre a $\mathrm{C}_{\mathrm{WSW}}(13,7 \%)$, a $C(12,4 \%)$, a $C_{\mathrm{SE}}(8,9 \%)$ és a $\mathrm{C}_{\mathrm{NE}}(8,1 \%)$. Míg a legcsapadékosabb anticiklonális típus ebben az évszakban az $\mathrm{A}_{\mathrm{NE}}(15,6 \%)(5 a$. táblázat). Ósszel a ciklonális és az anticiklonális típusok előfordulása rendre $83,7 \%$ és $16,3 \%$. Ekkor a legcsapadékosabb évszak a C (17,2\%), amelyet csökkenő sorrendben a $\mathrm{C}_{\mathrm{WSW}}(16,6 \%)$, a $\mathrm{C}_{\mathrm{SSW}}(14,3 \%)$ és a $\mathrm{C}_{\mathrm{SE}}(14,1 \%)$ követ.

Érdekes módon, évi összevetésben lényegesen kevesebb csapadék jellemző a ciklonális típusokra $(64,5 \%)$ az empirikus osztályozás esetében $(5 b$. táblázat), összehasonlítva az objektív osztályozással (77,4\%) (5a. táblázat). Másrészről az anticiklonális eredetű csapadék mennyisége jóval nagyobb az empirikus típusoknál (35,4\%). A legcsapadékosabb ciklonális típusok csökkenő sorrendben rendre a következők: CMw $(19,9 \%), \mathrm{mCw}(16,4 \%)$, mCc $(12,5 \%)$ és C $(8,4 \%)$ (5b.táblázat). Télen az összes lehulló csapadék 67,0\%-a köthető a ciklonális, míg a fennmaradó 33,0\% az anticiklonális típusokhoz. Ezek az arányok lényegesen eltérnek az objektív típusokéitól ( $5 a$., 5b.táblázat). A legtöbb csapadék az mCw $(25,1 \%)$ és a CMw $(21,6 \%)$ ciklonális típusokhoz kapcsolódik, míg a legcsapadékosabb anticiklonális típus az Ae (12,9\%) (5b.táblázat).

Tavasszal az összes csapadék 70,5\%-a hullik ciklonális típusok fennállásakor, míg 29,5\%-a anticiklonális típusok előfordulásakor. Ezek az adatok - a téli értékekhez hasonlóan - lényegesen eltérnek az objektív osztályozás megfelelő adataitól. A legnagyobb csapadékmennyiségekhez kapcsolódó ciklonális típusok csökkenő sorrendben rendre a következők: CMw (2,9\%), mCc (14,7\%), mCw (14,6\%) és C (10,2\%). Ugyanakkor az anticiklonális típusok közül az An a legcsapadékosabb (7,9\%) (5b. táblázat; 3. ábra).

Nyáron a ciklonális típusoknál - az objektív osztályozáshoz hasonlóan - a legkevesebb a csapadék az összes évszakot figyelembe véve (53,9\%). Pontosabban, a legnagyobb csapadékmennyiségek csökkenő sorrendben rendre a következő típusokhoz tartoznak: mCc $(15,5 \%), \mathrm{C}(12,0 \%), \mathrm{mCw}(11,2 \%)$ és $\mathrm{CMw}(9,1 \%)$. Ugyanakkor a csapadékmennyiség ebben az évszakban a legmagasabb az anticiklonális típusoknál $(46,1 \%)$. A leginkább csapadékérzékeny anticiklonális típusok az Aw (11,1\%) és az An $(10,6 \%)$ (5b. táblázat). 


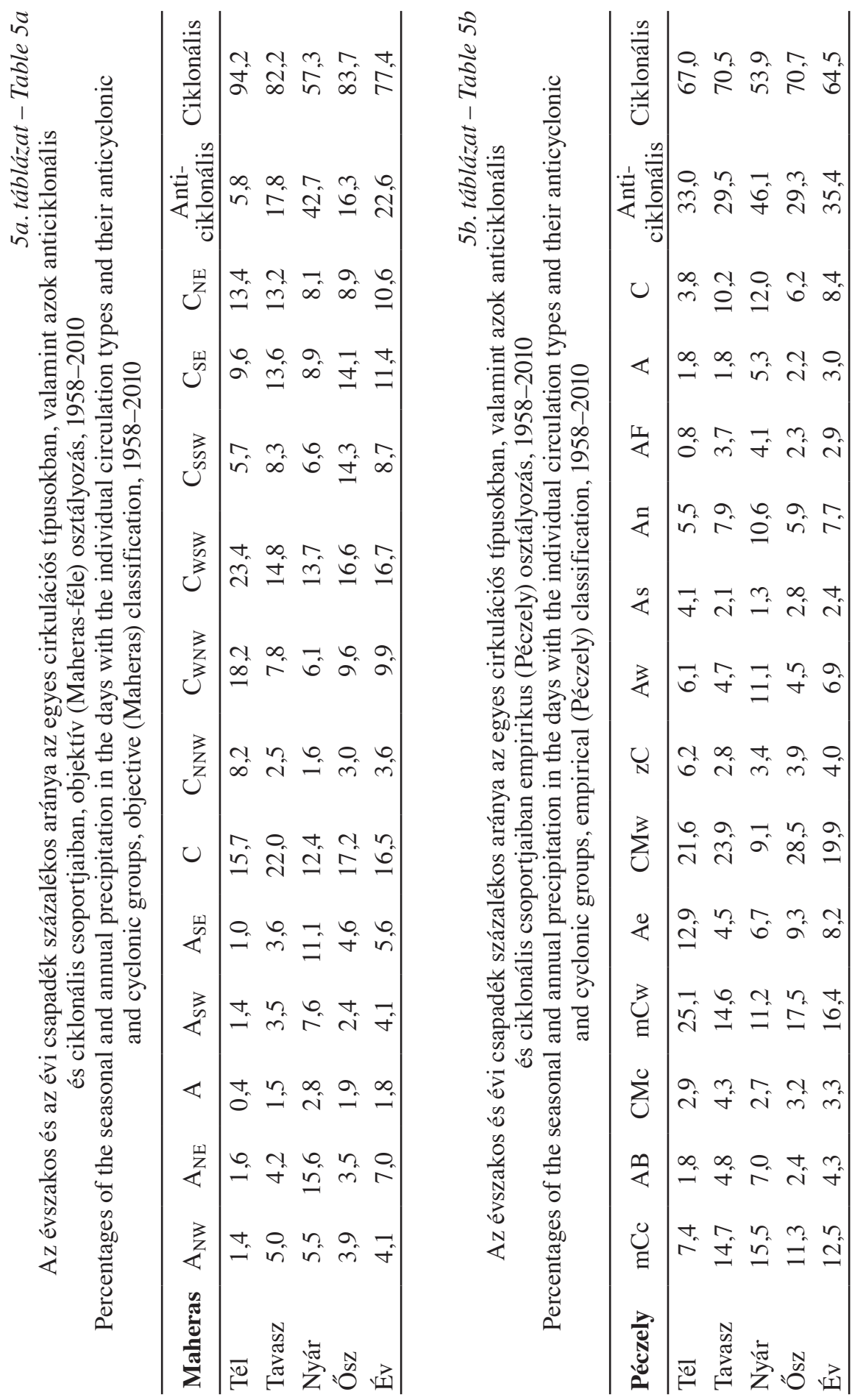


Ősszel a ciklonális típusok a legcsapadékosabbak (70,7\%), míg az anticiklonálisak a legszárazabbak $(29,3 \%)$. Ezek az értékek itt is lényegesen eltérnek az objektív osztályozás szerinti értékektől. A ciklonális típusok közül a legcsapadékosabb a CMw (28,5\%), s ez az arány a legmagasabb az összes típus közül mind a négy évszakra, és mindkét osztályozást figyelembe véve. A másik két legcsapadékosabb típus az mCw (17,5\%) és az mCc $(11,3 \%)$. Az anticiklonális típusok közül az Ae $(9,3 \%)$ a legcsapadékosabb (5b. táblázat).

\section{Következtetések}

Amikor a Kárpát-medencére vonatkozóan összehasonlítjuk az egymástól számottevően eltérő automatizált (objektív) és empirikus (szubjektív) osztályozási módszereket (az utóbbiak a 19. sz. végétől eredeztethetốek), megállapíthatjuk, hogy az empirikus anticiklonális (ciklonális) típusok gyakorisága mind az évi, mind pedig az évszakos összevetésben jóval nagyobb (kisebb), mint az objektív anticiklonális (ciklonális) típusoké. Ez részben annak a ténynek tulajdonítható, hogy eltérő módszereket alkalmaztunk a kétféle osztályozás kritériumaiként.

Figyelembe véve, hogy a napi anomália-értékeket külön-külön minden egyes hónapra kiszámítottuk az 1971-2000 közötti 30 éves időszak 1000 hPa-os abszolút topográfiái havi közepes geopotenciális magasságainak a felhasználásával, nyilvánvaló, hogy ha az osztályozási rendszerben felhasznált, Magyarország körüli 9 rácspont geopotenciál-értékeinek havi átlaga magas (pl. télen), akkor az osztályozási rendszer valószínúen több ciklonális típust tartalmaz, mint amikor a 9 rácspont anomáliáinak havi átlaga alacsony (pl. nyáron). Ami a manuális módszereket illeti, a típus a tipizáló szubjektív megítélésétól függ. Emiatt a típusok szubjektíve túlzóak lehetnek. Pl. a különböző kutatók nem fognak feltétlenül egyetértésre jutni egy adott nap tipizálásában. Egy másik lehetőség a tipizálók eltérő személye miatt fellépő technikai hibák nagy valószínúsége, ami az általunk tárgyalt empirikus tipizálásra is jellemző (PÉCZELY Gy. 1961, 1983; KÁROSSY Cs. 2016).Ezen kívül, az empirikus tipizálás nem a legjobb módja az eltérő típusok egymástól történő elkülönítésének, mivel gyakran fokozatos átmenet vezet át az egyikből a másikba (PHILIPP, A. et al. 2010), ami különösen a frontok áthaladásához kapcsolódó nyomásmezőket jellemzi Magyarországon. Az 1000 hPa-os légnyomási szint legmagasabb geopotenciál-értékei télen tapasztalhatók, amikor ezen értékek eltérései a legnagyobbak az anticiklonális és a ciklonális típusok között, mindkét osztályozási rendszer esetében (6.táblázat). az anticiklonális és a ciklonális típusok gyakoriságai közötti eltéréseket tanulmányukban BARTHOLY, J. és szerzőtársai említik (BARTHOLY, J. et al. 2009). Eredményeik alapján a negatív NAOfázisban a ciklonális típusok gyakoribbak, míg az index pozitív fázisában az anticiklonális típusoknak nagyobb a gyakorisága. [A NAO (North Atlantic Oscillation = Észak-atlanti Oszcilláció) idốjárási jelenség az Atlanti-óceánban, amely az izlandi alacsony nyomású és az azori magas nyomású hatásközpontok légnyomásai eltéréseinek fluktuációit foglalja magába (HuRRELL, J. W. et al. [eds] 2013)].

Budapest napi csapadékmennyiségeit évi és évszakos összevetésben vizsgálva, a legnagyobb csapadékmennyiségek - függetlenül a használt osztályozástól - bizonyos cirkulációs típusokhoz kapcsolódnak: az objektív osztályozás esetében ezek a $\mathrm{C}, \mathrm{C}_{\mathrm{WSW}}, \mathrm{C}_{\mathrm{SE}}$ és $\mathrm{C}_{\mathrm{NE}}$ típusok, míg az empirikus osztályozásnál ezek a $\mathrm{CMw}, \mathrm{mCw}, \mathrm{mCc}$ és $\mathrm{C}$ típusok. Ez az eredmény összhangban van MiKA et al. (2013) megállapításaival, amelyek szerint a Péczely-féle osztályozásnál a legnagyobb átlagos csapadékösszegek a ciklonális típusokhoz (CMw, mCw és C) kapcsolódnak. Összességében az objektív osztályozásnál a ciklonális (anticiklonális) típusok felelősek az évi össz-csapadék 77,4\%-áért (22,6\%-áért). Ezzel 
Az 1000 hPa-os abszolút topográfia (objektív osztályozás), valamint a tengerszinti légnyomás (empirikus osztályozás) havi közepes értékei, Budapest $\left(\mathrm{j}=47,5^{\circ} \mathrm{N}, 1=20,0^{\circ} \mathrm{E}\right)$

Monthly mean values of the $1000 \mathrm{hPa}$ absolute topography (objective classification) and the sea level pressure (empirical classification), Budapest $\left(j=47,5^{\circ} \mathrm{N}, 1=20,0^{\circ} \mathrm{E}\right)$

\begin{tabular}{lrccrrr}
\hline $\begin{array}{l}\text { Légnyomási } \\
\text { felületek }\end{array}$ & Január & Február & Március & Április & Május & Június \\
\hline $1000 \mathrm{hPa}(\mathrm{m})$ & 165,8 & 150,9 & 135,8 & 112,2 & 121,5 & 122,9 \\
$\mathrm{SLP}(\mathrm{mb})$ & 1019,8 & 1018,0 & 1016,2 & 1013,2 & 1014,2 & 1014,0 \\
\hline & & & & & & \\
\hline $\begin{array}{l}\text { Légnyomási } \\
\text { felületek }\end{array}$ & \multirow{2}{*}{ Július } & Augusztus & Szeptember & Október & November & December \\
\hline $1000 \mathrm{hPa}(\mathrm{m})$ & 126,5 & 130,2 & 147,9 & 159,3 & 149,8 & 154,6 \\
$\mathrm{SLP}(\mathrm{mb})$ & 1014,2 & 1014,7 & 1017,0 & 1018,8 & 1017,7 & 1018,4 \\
\hline
\end{tabular}

szemben az empirikus típusoknál ezek az arányok rendre 64,5\%, illetve 35,5\% értékúek a ciklonális, illetve az anticiklonális típusok esetében. A két osztályozásnál a csapadékösszeg megfigyelt eltérései az évi, illetve az évszakos összesítésben valószínúleg arra vezethetők vissza, hogy a ciklonális típusok jóval gyakoribbak az objektív osztályozásnál, szemben az empirikus osztályozással.

Miután kiszámítottuk a két osztályozási rendszer cirkulációs típusainak a gyakoriságai közötti korrelációs együtthatókat, megállapítottuk, hogy az évszakos anticiklonális és ciklonális típusok közötti legnagyobb és statisztikailag szignifikáns korrelációk télen lépnek föl mindkét osztályozási rendszerben. Jóllehet szignifikáns korrelációs együtthatók a többi évszakban is kimutathatók, azok nem érik el a téli magas értékeket. Ennek lehetséges okai a következők: (1) a vizsgált osztályozási módszereknek a fentiekben elemzett eltérései; (2) eltérő mérési szintek (az 1000 hPa-os abszolút topográfia geopotenciális magassági értékei, illetve a tengerszinti magasság); (3) az osztályozási módszerek eltéró volta. Végül - miután összehasonlítottuk az objektív és az empirikus osztályozások cirkulációs típusainak gyakoriságait - megállapítottuk, hogy vannak olyan típusok az egyik osztályozásban, amelyek általában jelentős százalékos aránnyal kapcsolódnak bizonyos típusokhoz a másik osztályozásban.

Összességében úgy látjuk, hogy mindkét osztályozási rendszerre igaz: nemcsak számottevő elónyeik vannak, hanem egyúttal kimutatható néhány hátrányuk is. Az empirikus osztályozás egyik legnagyobb előnye, hogy meglehetôsen kevés (13) cirkulációs típust tartalmaz, emiatt viszonylag egyszerú értelmezni és interpretálni az eredményeket. Ezenkívül - abból adódóan, hogy ez az osztályozási rendszer igen hosszú időszakra (1883-tól a jelen időig) lett kiterjesztve - igen hasznos eszköz lehet a Kárpát-medence cirkulációs viszonyainak hosszú időszakra történő tanulmányozásában. Egy másik fontos szempont, hogy ez a 13 típus 5 fó csoportba sorolható a légtömegek Kárpát-medence fölötti áramlási viszonyai alapján. Ugyanakkor e megközelítés hátrányai leginkább ahhoz kapcsolódnak, hogy miközben a ciklonális típusok gyakoriságai pozitív trendet mutatnak, a csapadékmennyiségek negatív trendet jeleznek. Továbbá, bár az anticiklonális típusok előfordulása összességében negatív trendet jelez, a Budapestet reprezentáló rácspontban a tengerszinti légnyomásértékek trendje pozitív. Az empirikus osztályozás hátrányai ellenére mindkét osztályozás meglehetôsen jól reprodukálja a havi és regionális skálájú csapadékstatisztikákat. 
Összegezve, az objektív osztályozási rendszer előnye, hogy az anticiklonális és ciklonális időjárási típusok trendjei összhangban vannak a budapesti csapadéktrendekkel, valamint a tengerszinti légnyomás és az 1000 hPa-os abszolút topográfia geopotenciális magasságainak trendjeivel. Ezek a megállapítások jól egyeznek az Európára (KYSELÝ, J.-HuTH, R. 2006) és Kelet-Európára (BARTOSZEK, K. 2017) kapott eredményekkel.

Az objektív osztályozás hátrányai az alábbiak:

1. Az osztályozási rendszert minden alkalommal egy földrajzilag behatárolt területre alkalmazzuk ugyanakkor az osztályozás eredményei, a napi típus-sorok nem értelmezhetôk egy másik, akár szomszédos területre.

2. A rendszer a regionális földrajzi tényezők (pl. felszíndomborzat) révén kellően érzékeny a geopotenciális értékek bármilyen változására.

A szerzők a jövőben elemezni kívánják az átlagos és az extrém napi csapadékösszegeket abból a célból, hogy kiderítsék, azok miként kapcsolódnak az objektív időjárási típusokhoz.

KLICÁSZ SZPIROSZ

Zrínyi Miklós Gimnázium, Budapest

spiros@hwr.hu

PANAGIOTIS MAHERAS

Department of Meteorology and Climatology, Aristotle University of Thessaloniki, Greece maheras@geo.auth.gr

Konstantina TOLIKA

Department of Meteorology and Climatology, Aristotle University of Thessaloniki, Greece diatol@geo.auth.gr

IOANNIS TEGOULIAS

Department of Meteorology and Climatology, Aristotle University of Thessaloniki, Greece tegoulia@auth.gr

Christina Anagnostopoulou

Department of Meteorology and Climatology, Aristotle University of Thessaloniki, Greece chanag@geo.auth.gr

KÁROSSY CSABA

ELTE Savaria Egyetemi Központ, Szombathely

c.karossy@gmail.com

MAKRA LÁSZLÓ

Szegedi Tudományegyetem Mezőgazdasági Kar, Hódmezővásárhely

makra@geo.u-szeged.hu

IRODALOM

Anagnostopoulou, C.-Flocas, H.-Maheras, P.-Patricas, I. 2004: Relationship Between Atmospheric Circulation Types Over Greece and Westem-Central Europe During the Period 1958-97. - International Journal of Climatology 24. pp. 1745-1758.

Anagostopoulou, C.-Tolika, K.-Maheras, P. 2009: Classification of circulation types: a new flexible automated approach applicable to NCEP and GCM datasets. - Theoretical and Applied Climatology 96. pp. 3-15.

BARtholy, J.-Pongrácz, R.-Gelybó, Gy. 2009: Climate signals of the North Atlantic oscillation detected in the Carpathian basin. - Applied Ecology and Environmental Research 7. pp. 229-240. 
BARTOSZEK, K. 2017: The main characteristics of atmospheric circulation over east-central Europe from 1871 to 2010. - Meteorology and Atmospheric Physics 129. pp. 113-129.

Hurrell, J. W.-Kushnir, Y.-Ottersen, G.-Visbeck, M. (eds) 2013: The North Atlantic Oscillation: Climatic Significance and Environmental Impact. - Geophysical Monograph Series, 134. American Geophysical Union, Washington D C, doi: 10.1029/GM134, ISBN 9780875909943

Jones, P. D.-Hulme, M.-BRIFIA, K. R. 1993: A comparíson of Lamb circulation types with an objective classification scheme. - International Journal of Climatology 13. pp. 655-663.

Kalnay, E.-Kanamitsu, M.-Kistler, R.-Collins, W.-Deaven, D.-Gandin, L.-Iredell, M.-Saha, S.-White, G.-Woollen, J.-Zhu, Y.-Chelliah, M.-Ebisuzaki, W.-Higgins, W.-Janowiak, J.-Mo, K.C.-Ropelewski, C.-WAng, J.-LeetmaA, A.-Reynolds, R.-Jenne, R.-JosePh, D. 1996: The NCEP/ NCAR 40-year reanalysis project. - Bulletin of the American Meteorological Society 77. pp. 437-471.

KÁRossy, Cs. 2004: Péczely’s macrosynoptic types, 1988-2003. Manuscript (in Hungarian).

KÁRossy Cs. 2016: A Kárpát-medence Péczely-féle makroszinoptikus helyzeteinek a katalógusa (1881-2015). (Catalog of the Péczely's macrosynoptic types for the Carpathian Basin.) - OSKAR, Szombathely (in Hungarian).

Kassomenos, P. A.-Gryparis, A.-Katsouyanni, K. 2007: On the association between daily mortality and air mass types in Athens, Greece during winter and summer. - International Journal of Biometeorology 51. pp. 315-322.

KyselÝ, J.-Huth, R. 2006: Changes in atmospheric circulation over Europe detected by objective and subjective methods. - Theoretical and Applied Climatology 85. pp. 13-36.

Kutiel, H.-Benaroch, Y. 2002: North Sea - Caspian pattem (NCP) - an upper level atmospheric teleconnection affecting the eastern Mediterranean: identification and definitions. - Theoretical and Applied Climatology 71.pp. 17-28.

Kutiel, H.-MAheras, P.-TÜRKeş, M.-PAZ, S. 2002. North Sea-Caspian pattern - an upper level atmospheric teleconnection affecting the eastem Mediterranean - implications on the regional climate. - Theoretical and Applied Climatology 72. pp. 173-192.

LANDAU, S.-EveritT, B. S. 2004: Handbook of Statistical Analyses using SPSS. - Chapman \& Hall/CRC Press LLC; Boca Raton, London, New York, Washington, D.C. ISBN 1-58488-369-3

Maheras, P.-Kutiel, H. 1999a: Wet and dry monthly anomalies across the Mediterranean basin and their reladonship with circulation 1860-1990. - Theoretical and Applied Climatology 64. pp. 189-199.

Maheras, P.-Xoplaki, E.-Davies, T.-Martin-Vide, J.-Bariendos, M.-Alcoforado, M. 1999b: Warm and cold monthly anomalies across the Mediterranean basin and their relationship with circulation: 1860-1990. - International Journal of Climatology 19. pp. 1697-1715.

Maheras, P.-Patrikas, I.-Karacostas, T.-Anagnostopoulou, C. 2000a: Automatic classification of circulation types in Greece. methodology, description, frequency, variability and trend analysis. - Theoretical and Applied Climatology 67. pp. 205-223.

Maheras, P.-PAtrikas, I.-Anagnostopoulou, C. 2000b: An objective classification of circulation types in Greece. - In: Proceedings of Hellenic Conference of Meteorology, Climatology.-Physics of the Atmospheric Sciences, National Hellenic Research Foundation, Thessaloniki, Greece. pp. 25-33.

MAKRA, L. 2005: Relation of pollutant concentrations to the Peczely's large scale weather situations in Szeged, Southern Hungary. - Epidemiology 16. pp. S63-S63.

MAKRA, L. 2006: Comparison of Objective Air-mass Types and the Peczely Weather Types and their Ability of Classifying Airborne Pollen Grain Concentrations in Szeged, Hungary. - Epidemiology 17. pp. S292-S293.

Makra, L.-MikA, J.-BARTzokAs, A.-SüMeghy, Z. 2007a: Relationship between the Péczely's large-scale weather types and air pollution levels in Szeged, Southern Hungary. - Fresenius Environmental Bulletin 16. pp. 660-673.

Makra, L.-Juhász, M.-Mika, J.-BARtzokas, A.-BÉCZi, R.-SüMEghy,Z. 2007b: Relationship between the Péczely's large-scale weather types and airborne pollen grain concentrations for Szeged, Hungary. - Grana 46. pp. 43-56.

MAKRA,L.-MikA, J.-BARTZOKAs, A.-BÉCZI, R.-SÜMEGHY,Z. 2009: Comparison of objective air-mass types and the Péczely weather types and their ability to classify levels of air pollutants in Szeged, Hungary. In: MAKRA L.-KAmBEZIDIS, H. D. (eds): International Journal of Environment and Pollution. "Air Pollution" Special Issue 36. pp. 81-98.

MAKRA L. 2012: Különböző taxonok pollenjeinek komplex statisztikai elemzése a meteorológiai elemekkel összefüggésben, különös tekintettel a parlagfú pollenjére. - Kézirat. dc_299_11, University of Szeged, Szeged, Hungary (in Hungarian), 123 p. OAI identifier: oai:real-d.mtak.hu:513, http://real-d.mtak.hu/513/

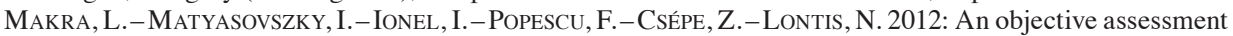
of the connection between meteorological elements and the main air pollutant levels at Szeged, Hungary. - Proceedings of the $7^{\text {th }}$ WSEAS International Conference on Energy \& Environment. Recent Researches 
in Environmental \& Geological Sciences. (Eds: Altawell, N.-Volkov, K.-Matos, C.-De Arroyabe P. F.) pp. 87-92. ISBN: 978-1-61804-110-4

PÉCZELy Gy. 1961: Magyarország makroszinoptikus helyzeteinek éghajlati jellemzése. - A Központi Meteorológiai Intézet Kisebb Kiadványai, Budapest. 32.128 p.

PÉCZELY Gy. 1983: Magyarország makroszinoptikus helyzeteinek katalógusa (1881-1983). - Az Országos Meteorológiai Szolgálat Kisebb Kiadványai, Budapest. 53. 116 p.

Philipp, A.-Bartholy, J.-Beck, C.-Erpicum, M.-Esteban, P.-Fettweis, X.-Huth, R.-James, P.-Jourdain, S.-Kreienkamp, F.-Krennert, T.-Lykoudis, S.-Michalides, S.-Pianko-Kluczynska, K.-Post, P.-Rassilla Álvarez, D.-Schiemann, R.-Spekat, A.-Tymvios, F.S. 2010: COST733CAT - a database of weather and circulation type classifications. - Physics and Chemistry of the Earth 35. pp. 360-373.

SHERIDAN, S. C. 2002: The redevelopment of a weather type classification scheme for North America. - International Journal of Climatology 22. pp. 51-68.

VAN LOON, H.-Rogers, J. C. 1978: The seesaw in winter temperature between Greenland and northem Europe. Part I: general description. - Monthly Weather Review 106. pp. 296-310. 